\title{
Pengadilan HAM dan Yurisdiksi Pengadilan Internasional
}

\author{
Sefriani
}

\begin{abstract}
This article attempts to describe establishment and jurisdiction of several international court that their duty related with the crime of humanity, war crime, and genocide especially the international criminal court (ICC). This article also attemts to respons what will be happened if the Indonesian ad hoc tribunal for the serious human right violation in East Timor failed realized its duty. Is it true that the accused will be bring to justice by ICC? Is it ICC has jurisdiction over serious human right violation in East Timor? How about with Semanggil and II also Tanjung Priok cases? That questions will be respons by this article.
\end{abstract}

\section{Pendahuluan}

Ditetapkannya UU 39 Tahun 1999 tentang Hak Asasi Mnausia (HAM), UU No. 26 Tahun 2000 tentang Pengadilan HAM, dipilihnya hakim-hakim ad hoc, sampai segera akan digelarnya peradilan pelanggaran HAM Timor Timur pasca jajak pendapat merupakan langkah-langkah yang ditempuh Pemerintah Indonesia untuk menunjukkan pada masyarakat internasional niat pemerintah untuk mengadili pelaku-pelaku pelanggaran tersebut.

Hal ini sangat penting mengingat desakan sekaligus ancaman masyarakat internasional untuk menyeret para pelaku pelanggaran HAM Timor Timur ke pengadilan internasional jika pemerintah tidak mengambil tindakan tegas terhadap mereka. Sekretaris Jendral PBB Kofi Annan dalam kunjungannya ke Jakarta dan Timor Timur pada Februari 2000 menegaskan bahwa pihaknya berjanji bahwa pihak-pihak yang terbukti melakukan pelanggaran HAM semasa dan pasca penentuan pendapat rakyat Timor Timur Agustus 2000 akan dibawa ke pengadilan internasional. ${ }^{1}$ Di samping itu, Ketua komisi HAM PBB Marry Robinson dalam

'Harian Kompas. Tanggal 19 Februari 2000 
kunjungannya ke Indonesia beberapa waktu yang lalu juga menyerukan ancaman yang sama.

Dalam kaitannya dengan kasus Timor Timur banyak pihak beranggapan bahwa para pelaku pelanggaran HAM Timor Timur akan segera diajukan ke International Criminal Court (ICC) yang dibentuk tahun 1998 yang lalu, bila Indonesia tidak mau dan atau tidak mampu mengadili sendiri para pelakunya.

\section{International Criminal Tribunal for The Former Yugosiavia}

International Criminal Tribunal for The Former Yugoslavia (ICTY) merupakan pengadilan internasional ketiga yang dibentuk untuk mengadili individu-individu pelaku kejahatan terhadap kemanusiaan, kejahatan perang, pelanggaran berat Konvensi Jenewa 1949 serta genocide. Pengadilan internasional pertama dan kedua dibentuk oleh Sekutu sebagai pemenang perang (Amerika Serikat, Perancis, Inggris, Rusia) pada $1946 \mathrm{di}$ Nurenberg dan 1949 di Tokyo untuk kasus kejahatan perang pada Perang Dunia ke $\mathrm{II}^{2}$ Dari dua pengadilan pertama ini lahir suatu ketentuan hukum yang sangat fundamental dalam hukum internasional yakni menempatkan individu sebagai subjek hukum internasional. Ketentuan hukum internasional sebelumnya tidak memasukkan individu sebagai subjek hukum internasional, maka tidak demikian halnya dari putusan pengadilan tahun 1946 dan 1949 tersebut. Menurut pandangan pengadilan internasional saat itu "Kejahatan terhadap hukum internasional dilakukan manusia, bukan oleh kesatuan abstrak, dan hanya menghukum individuindividu yang melakukan kejahatan demikian, ketentuan-ketentuan hukum internasional dapat dijalankan". Dengan demikian Individu tidak dapat lagi berlindung dibalik negaranya terhadap kejahatan-kejahatan (kejahatan perang) yang dilakukannya ${ }^{3}$

ICTY dibentuk oleh Dewan Keamanan Perserikatan Bangsa Bangsa (DK PBB) melalui Resolusinya Nomor 827 tanggal 25 Mei 1993. Tugas, kewenangan, dan mekanisme kerja ICTY diatur dalam Statute of ICTY 1993. Berdasarkan Pasal 1 Statuta, tugas ICTY yang berkedudukan di Den Haag tersebut adalah untuk mengadili orang-orang yang bertanggung jawab atas pelanggaranpelanggaran berat terhadap hukum humaniter internasional yang terjadi di negara bekas Yugoslavia sejak 1991. Yurisdiksi ICTY adalah sebagai berikut: ${ }^{4}$ 1) Grave breaches of the Geneva Convention of 1949; 2) Violation of the Laws or Customs War; 3) Genocide; 4) Crimes against humanity

${ }^{2}$ Romli Atmasasmita. 1995. Pengantar Hukum Pidana Internasional. Bandung: Eresco. Hlm. 51

${ }^{3}$ Michael Akehurst. 1983. A Modern Introduction to International Law. Ondon: George Allan \& Unwin (Publishers) Ltd. Hlm. 216

${ }^{4}$ Roberge, Maria Claudia. "Jurisdiction of ad hoc Tribunal for The Former Yugoslavia \& Rwanda over Crimes Against Humanity and Genocide." Dalam International Review of Red Cross. No.322. NopemberDesember 1997. HIm.651 
Sampai dengan akhir tahun 2000 sudah 84 orang $^{5}$ dituduh melakukan pelanggaranpelanggaran berat, Dua puluh diantaranya sudah ditahan. ${ }^{6}$ Mereka dituduh melakukan kejahatan terhadap umat manusia dan melanggar hukum atau kebiasaan perang. Pada 3 Maret 2000, Mahkamah menjatuhkan penjara 45 tahun kepada Jendral Kroasia Bosnia Tihomir Blaskic yang telah mengorganisir ethnic cleansing terhadap orang-orang muslim selama perang Bosnia 1992-1995.Jendral paling senior ini juga dituduh melakukan pelanggaran berat terhadap Konvensi Jenewa 1949. Putusan mahkamah menyatakan bahwa Blaskic tidak membunuh orang-orang muslim dengan tangannya sendiri, tetapi ia tetap bersalah karena tidak berusaha mencegah terjadinya kejahatan-kejahatan dan menghukum pelakunya?

Dalam upayanya menangkap para tertuduh, ICTY yang tidak memiliki polisi sendiri cukup kesulitan, terpaksa harus mengandalkan kerjasama penguasa suatu negara dimana para tertuduh berada ${ }^{8}$. Dalam hal ini memang negara-negara bekas Yugo- slavia kurang menunjukkan kerjasama dengan ICTY, sehingga masih banyak orangorang penting yang menjadi tertuduh masih menduduki jabatan-jabatan penting pemerintahan di negaranyá. Menanggapi permasalahan ini, DK PBB memang telah mengeluarkan resolusi-resolusi No.1160,1199, 1203,dan 1207 yang menegaskan hak penuntut umum untuk melakukan pemeriksaan di Kosovo dan mewajibkan Republik Federal Yugoslavia bekerjasama dengan ICTY' , tetapi resolusi tersebut belum ditaati sepenuhnya oleh pemerintah Yugoslavia, masih banyak para tertuduh yang tidak diserahkan ke ICTY, malah justru dilindungi dan diberi kedudukan penting di pemerintahan.

International Criminal Tribunal for Rwanda

International Criminal Tribunal for Rwanda (ICTR) yang berkedudukan di Arusha, Tanzania ini dibentuk melalui Resolusi DK PBB No 955, tanggal 8 Nopember 1994. Tugas utamanya adalah meminta pertanggungjawaban para pelaku

${ }^{5}$ Rodovan Karadzic, Ratco Mladic, Sobodan Milosevic (Presiden republik Federasi Yugoslavia), Milan Milutinovic (Presiden Serbia), Draguljob Ojdanic (Kepala Tentara Yugoslavia), termasuk diantara mereka. Namanama orang penting lainnya dapat ditemukan dalam $A$ Global Agenda, Issues before the $54^{\text {th }}$ General Assembly of The U.N. 1999-2000 Edition. HIm. 264

${ }^{6} /$ bid.

${ }^{7}$ International Herald Tribune. March 4-5. 2000. HIm. 11

${ }^{9}$ Penangkapan Slobidan Milosevic beberapa waktu yang lalu merupakan hasil kerjasama dengan penguasa setempat dengan imbalan bantuan keuangan untuk pembangunan Yugoslavia, Harian Kompas. Tanggal $2 \mathrm{Juli}$ 2001.

${ }^{9}$ Boer Mauna. 2000. Hukum Internasional Pengertian, Peranan dan Fungsi dalam Era Dinamika Global. Bandung: Alumni. HIm.265 
pembunihan masal sekitar 800.000 orang Rwanda terutama dari suku Tutsi. Beberapa putusan berkisar $25-80$ tahun penjara telah dijatuhkan pada mantan pejabat-pejabat penting Rwanda, seperti Bupati, Walikota sampai Perdana Mentri khususnya yang berasal dari suku Hutu, juga kepada milisi Hutu. Dalam putusannya ICTR menyatakan bahwa para tertuduh terbukti terlibat baik secara langsung maupun tidak langsung dalam tindakan-tindakan kekerasan pemusnahan etnis yang terencana dan terorganisir sebelumnya. ${ }^{10}$

Berbeda dengan ICTY, ICTR dalam melaksanakan tugasnya mendapat dukungan dan kerjasama yang baik dari negara-negara Afrika lainnya untuk menyerahkan para tertuduh yang kedapatan ada di wilayahnya. Sebagai contoh mantan Menteri Kehakiman Rwanda Mathieu Ngirumpatse ditangkap pada 11 Juni 1998 di Mali yang kemudian diserahkan pada ICTR. Penyerahan juga dilakukan oleh Kenya dan Afrika Selatan terhadap Dr Casimir Bizimungu, Eliezer Niyitegeke dan Ignace Bagilishema para mantan pejabat sipil dan militer yang dituduh sebagai penjahat perang. Kerjasama juga diperoleh dari negara-negara barat. Perancis, misalnya pada tanggal 8 Maret 2000 menyerahkan Jean de Dieu Kamuhanda yang dituduh melakukan perbuatan pemusnahan ras dan kejahatan terhadap kemanusiaan ke ICTR ketika yang bersangkutan berada di wilayahnya. Perancis juga sedang mengupayakan pemindahan FranchoisXavier Nzuwomeneye, mantan Perwira Tinggi Rwanda yang dituduh melakukan kejahatankejahatan terhadap kemanusiaan dan berhasil ditangkap di Mountauban, Perancis. Partisipasi aktif ini merupakan perkembangan positif bagi kegiatan ICTR ."

\section{Yurisdiksi International Criminal Court}

International Criminal Court (ICC) merupakan institusi yang bersifat permanen. Dasar pertimbangan dibentuknya institusi permanen ini adalah untuk efisiensi dan efektivitas penegakan pelanggaranpelanggaran HAM berat. Pasca operasional ICC diharapkan setiap pelanggaran HAM berat yang masuk yurisdiksi ICC segera dapat diadili tanpa harus menunggu pembentukan pengadilan baru, statuta baru, termasuk penunjukan aparat-aparat penegak hukumnya. Pembentukan pengadilan-pengadilan ad hoc dalam kasus-kasus sebelumnya selalu memakan waktu, biaya dan tenaga yang tidak sedikit. $^{12}$

Pengadilan internasional yang berkedudukan di Den Haag-Belanda ini dibentuk melalui Statuta Roma (Rome Statute)

\section{${ }^{10} \mathrm{bid}$}

"Ibid. 266

12Pembentukan pengadilan ad hoc melalui Resolusi Dewan Keamanan PBB, dimana memerlukan proses yang rumit dan lama, melalui pemungutan suara yang memerlukan kesepakatan bulat lima anggota tetap lembaga tersebut, contoh-contoh rumit dan lamanya proses resolusi DK itu dapat dilihat pada Thomas M. Franck. 1999. Fairness in International Law and Institution. Oxford: Clarendon Press. HIm. 259. Bandingkan dengan Sumaryo Suryokusumo. 1997. Studi Kasus Organisasi Internasional. Edisi ll. Bandung: Alumni. HIm. 32-33 
1998. Meskipun sama-sama berkedudukan di Den Haag namun institusi ini tidak ada kaitannya dengan lembaga pengadilan internasional lain yang merupakan salah satu organ utama PBB yaitu International Court of Justice (ICJ) atau yang lebih dikenal dengan Mahkamah Internasional. ICJ dibentuk bersamaan dengan dibentuknya PBB pada tahun 1945, statutanya pun melekat pada piagam PBB (The Charter of United Nations). Bilamana pihak yang dapat diajukan pada ICJ adalah hanya negara (State) maka pada ICC adalah individu. Meskipun berkedudukan di Den Haag Belanda, ICC dapat menyelenggarakan sidang-sidangnya di negara-negara lain sesuai kebutuhan.

Statuta Roma terdiri dari 125 pasal dan $13 \mathrm{bab}$, antara lain mengatur mengenai pembentukan ICC (bab-1), yurisdiksi, Admissibility dan Hukum yang digunakan (applicable law) Bab-2, prinsip-prinsip umum hukum pidana (bab-3), komposisi dan administrasi pengadilan (bab-4), investigasi dan penuntutan (bab-5), peradilan (trial Bab-6), penghukuman (penalties-bab-7), banding dan revisi (bab 8), kerjasama internasional dan bantuan yudisial (bab-9), enforcement (bab-10), Majelis negaranegara anggota (bab- 11), Keuangan (bab-12), dan klausula final (bab-13).

Badan-badan ICC adalah Presiden; Forum pra peradilan (Pre-Trial Division), Peradilan Tingkat pertama (Trial Division), dan Peradilan Tingkat Banding (Appeals Divisions); Penuntut Umum (Prosecutor) dan Panitia Pendaftar (Registry). Mahkamah akan memiliki 18 hakim ynag dipitih oleh Majelis Umum negara- negara pihak untuk periode selama 9 tahun. Hakim yang baru menyelesaikan tugasnya tidak dapat dipilih kembali, dan setiap negara pihak hanya dapat mengajukan satu orang calon hakim. Selanjutnya hakim ICC akan memilih presiden. Penuntut umum akan dipilih melalui pemungutan suara secara tertutup oleh Majelis umum. Hubungan antara Mahkamah dan PBB diatur secara tersendiri dalam suatu perjanjian yang memerlukan persetujuan Majelis Umum negara-negara pihak pada Statuta. ${ }^{13}$

Hakim ICC dijamin independensinya oleh Statuta Roma. Hakim harus independen dalam penampilan dan fungsinya. Hakim tidak boleh terikat pada kegiatan yang cenderung dapat mencampuri fungsi yudisial mereka dan mempengaruhi kepercayaan 'dan independensinya. Di samping itu, selama bertugas sebagai hakim ICC, para hakim tersebut tidak boleh bekerja pada pekerjaan atau instansi lain. ${ }^{14}$

Sebagaimana hakim yang dijamin independensinya demikian juga berlaku terhadap penuntut umumnya. Dikemukakan dalam statuta bahwa kantor penuntut umum akan bertindak secara independen sebagai organ terpisah dari peradilan dalam menjalankan tugas dan fungsinya. Kantor ini dikepalai oleh seorang kepala penuntut umum yang mempunyai otoritas penuh terhadap manajemen dan administrasi kantor, termasuk staf, fasilitas dan keperluan lainnya. Kantor penuntut umum akan bertanggung jawab untuk menerima pengaduan, penyerahan informasi yang mendukung

${ }^{13}$ Boer Mauna. Op.Cit. HIm 262.

${ }^{14} \mathrm{Pasal} 40$ Statuta Roma. 
terhadap kejahatan yang menjadi yurisdiksi peradilan, untuk mengujinya dan melakukan tindakan investigasi dan penuntutan sebelum peradilan. Penuntut umum bekerja independen dalam melaksanakan tugasnya. Kepala penuntut umum dapat menunjuk investigator untuk membantu pekerjaan mereka. ${ }^{15}$

Dalam kaitannya dengan yurisdiksi sebagaimana fokus tulisan ini, maka dapat dirujuk pada Pasal 5 Statuta yang menegaskan bahwa yurisdiksi ICC adalah pada kejahatankejahatan yang merupakan kejahatan paling serius dalam pandangan masyarakat internasional, mencakup sebagai berikut:
a. the crime of genocide
b. crimes against humanity
c. war crimes
d. the crime of agression

Kejahatan genocide menurut Pasal 6 statuta adalah setiap tindakan yang dilakukan dengan maksud untuk merusak seluruhnya atau sebagian, suatu bangsa, etnik, ras, atau kelompok agama tertentu, seperti pembunuhan anggota-anggota kelompok, menyebabkan bahaya yang serius terhadap tubuh atau mental anggota kelompok, dengan sengaja menimbulkan kerusakan-kerusakan fisik kondisi-kondisi kehidupan kelompok, melakukan tindakan-tindakan secara paksa dengan maksud untuk mencegah kelahiran dalam kelompok, dengan paksa memindahkan anak dari satu kelompok ke kelompok lain.

Kejahatan terhadap kemanusiaan menurut Pasal 7 Statuta adalah setiap tindakan yang dilakukan sebagai bagian dari serangan langsung yang luas atau sistematik terhadap penduduk sipil (civilian population), dengan pengetahuan tentang serangan. Tergolong dalam kejahatan terhadap kemanusiaan ini adalah pembunuhan, pemusnahan (extermination), perbudakan (enslavement), deportasi atau pemindahan paksa penduduk, pemenjaraan atau penghilangan kebebasan fisik secara kejam yang merupakan pelanggaran terhadap kaedah-kedah dasar hukum internasional, penyiksaan (torture), perkosaan, perbudakan sex, prostitusi secara paksa, kehamilan secara paksa, sterilisasi secara paksa, atau setiap bentuk lain dari kekerasan sexual, penyiksaan terhadap kelompok yang diidentifikasikan kolektivitas politik, ras, negara, etnis, budaya, agama, dan gender, penghilangan orang secara paksa, serta kejahatan apartheid. Di samping itu setiap tindakan lain yang di luar perikemanusiaan atau yang berkarakter sama yang dilakukan dengan sengaja dengan maksud untuk menimbulkan penderitaan yang sangat (great suffering), luka yang serius (serious injury) fisik maupun mental pada korban adalah termasuk juga dalam kategori kejahatan terhadap kemanusiaan. ${ }^{16}$

Kejahatan perang menurut Pasal 9 Statuta antara lain adalah pelanggaran-pelanggaran berat (grave breaches) terhadap Konvensi Geneva 1949. Tindakan-tindakan yang dimaksud antara lain pembunuhan dnegan sengaja, penyiksaan atau perlakuan tidak manusiawi termasuk eksperimen biologi,

15Pasal 42, 44 dan 53 Statuta Roma

${ }^{16}$ Pasal 7 Statuta Roma 1998 
dengan sengaja menyebabkan penderitaan yang berat atau luka yang serius terhadap tübuh, perusakan secara luas dan pengambilan milik yang tidak sah, memaksa tawanan perang atau orang-orang lain yang dilindungi untuk membantu kekuatan musuh, dengan sengaja menghilangkan hak-hak tawanan perang dan orang-orang yang dilindungi dari peradilan yang jujur dan reguler, deportasi dan pemenjaraan yang melawan hukum serta melakukan penyanderaan. ${ }^{17}$

Berkaitan dengan kejahatan agresi statuta tidak memberikan penjelasan sebagaimana 3 kategori kejahatan sebelumnya yang dijelaskan secara rinci dalam pasal-pasal tertentu. Mengenai kejahatan ini statuta hanya menjelaskan bahwa piagam PBB menjadi rujukan untuk kejahatan ini. ${ }^{18}$ Berkaitan dengan hal ini, Piagam juga tidak memberikan penjelasan mengenai kejahatan agresi., kecuali menetapkan bahwa berdasarkan $B A B$ VII Piagam DK berhak mengambil tindakantindakan secara bertahap sampai dengan pengerahan pasukan multinasional bilamana terjadi tindakan-tindakan yang mengancam perdamaian internaisonal serta pelanggaran agresi. 'Tidak adanya penjelasan mengenai apa yang dimaksud kejahatan agresi ini sedikit banyak tentu merupakan kelemahan bagi statuta. Hal ini dapat menimbulkan berbagai penafsiran dan berdampak pada tidak adanya kepastian hukum pada pihak-pihak yang dituduh melakukan kejahatan tersebut.
Berkaitan dengan masalah yurisdiksi, meskipun nampak jelas dari fakta-fakta yang ada telah terjadi kejahatan yang masuk kategori yurisdiksi ICC tidak serta merta para tertuduh dapat langsung dibawa ke ICC. Yurisdiksi ICC tidaklah wajib untuk semua negara. Hal ini diatur antara lain oleh Pasal 4 (2) Statuta yang menyatakan bahwa ICC dapat melaksanakan fungsi dan kekuasaannya sebagaimana diatur dalam statuta, di wilayah teritorial setiap negara, atau dengan perjanjian khusus di wilayah negara-negara lain. ${ }^{19}$

Selanjutnya masalah ini ditegaskan lagi dalam Pasal 12(1) Statuta yang menyatakan bahwa suatu negara yang menjadi peserta statuta karenanya menerima yurisdiksi ICC berkaitan dengan terjadinya 4 jenis kejahatan yang menjadi yurisdiksi sebagaimana yang diatur oleh Pasal 5 Statuta. Dengan demikian dapat disimpulkan bahwa yurisdiksi ICC hanya wajib atau otomatis berlaku sebatas negara peserta namun memerlukan suatu persetujuan khusus atau deklarasi terhadap negara-negara yang bukan peserta.

Di samping ketentuan di atas, ada beberapa hal penting dari ketentuan statuta yang patut digarisbawahi karena diprediksikan dapat menjadi hambatan bagi ICC dalam upayanya menegakkan hukum terhadap kejahatan-kejahatan yang menjadi lingkup yurisdiksinya. Pertama adalah mengenai berlakunya Statuta Roma yang nyata-nyata merupakan aturan dasar bagi operasional ICC. Pasal 126 Statuta menetapkan bahwa

${ }^{17}$ Pasal 8 Statuta Roma 1998 ${ }^{18}$ Pasal 5(2) Statuta Roma 1998

${ }^{19}$ Pasal 4(2) Statuta Roma 1998 
Statuta akan.berlaku pada hari pertama pada bulan setelah hari ke-60 dari didepositkannya instrumen ratifikasi, akseptasi, approval, atau aksesi yang ke-60 pada Sekretaris Jendral PBB. ${ }^{20}$ Dengan demikian Statuta baru akan berlaku setelah disahkan oleh 60 negara. Pada 17 Juli 2000 yang lalu baru 14 negara yang meratifikasi, sedangkan Indonesia belum menandatangani statuta tersebut. ${ }^{21}$ Perkembangan terakhir menunjukkan telah ada 118 negara yang sudah menandatangani, namun baru 24 negara yang meratifikasi. Amerika Serikat negara yang selalu mengklaim dirinya paling menghormati hak asasi manusia ternyata juga belum meratifikasi statuta tersebut. ${ }^{22}$

Hadirnya Statuta Roma dengan ICC-nya oleh beberapa negara dinilai mengganggu prinsip-prinsip kedaulatan, karena kejahatankejahatan yang terjadi di wilayahnya akan menjadi yurisdiksi ICC. Oleh karena itu, suatu negara akan berfikir berulang-ulang kali sebelum meratifikasi Statuta Roma mengingat akibat hukum dari ratifikasi tersebut adalah terikatnya mereka pada statuta yang berarti pula penundukan mereka pada yurisdiksi ICC. Kapan statuta akan berlaku tidak ada yang dapat memastikannya, ${ }^{23}$ mengingat ratifikasi dalam hukum internasional sifatnya tidak wajib, termasuk pada negara yang sudah menandatanganinya sekalipun.
Dari apa yang dikemukakan di atas nampak bahwa yurisdiksi ICC seandainya nanti sudah operasional sangatlah terbatas yaitu pada negara-negara peserta saja. Belajar dari kasus ICJ yang sarat dengan pembatasanpembatasan yurisdiksi seperti di atas sangat mempengaruhi wibawa lembaga yang bersangkutan. Dalam kasus Mahkamah Internasional tidak semua anggota PBB yang sebenarnya otomatis juga anggota statuta Mahkamah Internasional terikat atau tunduk pada yurisdiksi mahkamah. Perlu pernyataan sebelumnya (optional clause) untuk menerima yurisdiksi mahkamah ataupun kesepakatan sebelumnya dari negara yang bersangkutan sebelum perkaranya diajukan ke Mahkamah Internasional. Dengan keterbatasan yurisdiksi seperti ini, selama lebih dari 55 tahun beroperasi hanya sedikit sekali perkara yang menyangkut konflik hukum antar negara yang ditangani oleh Mahkamah Internasional.

Hal kedua dari ketentuan statuta yang diprediksikan dapat menjadi hambatan atau akan mengurangi efektivitas ICC adalah bahwa kedudukan ICC hanya sebagai institusi pelengkap bagi peradilan domestik yang dimiliki oleh masing-masing negara: Hal ini ditegaskan dalam Preambule paragraf 10 statuta yang menyatakan bahwa emphasizing that the ICC establishment under this statute

${ }^{20}$ Pasal 126(1) menetapkan bahwa This Statute shall enterinto force on the first day of the month after the $60^{\text {th }}$ day following the date of the deposit of the $60^{\text {h }}$ instrument of ratification, acceptance, approvalor accession with the Secretary-General of the United Nations

${ }^{21}$ Kompas. Tanggal 9 Agustus 2000. sebagaimana dikutip oleh Boer Mauna. Op.Cit. Him. 263

${ }^{22}$ Ronny Rahman Nitibaskara. "Pengadilan HAM dan Masyarakat Internasional." Dalam harian Kompas. Tanggal 20 Pebruari 2002

${ }^{23}$ Sebagai contoh dapat dikemukakan Konvensi Hukum Laut 1982 yang juga mensyaratkan 60 piagam ratifikasi untuk berlakunya memerlukan waktu 16 tahun untuk terpenuhinya persyaratan tersebut. 
shall be complementary to national criminal jurisdiction. Hal yang sama juga ditetapkan dalam Pasal 1 Statuta. ${ }^{24}$

Prinsip komplementanitas (complementarity principle) dalam Preambul maupun dalam Pasal 1 Statuta sebenarnya adalah untuk mengakomodasi pendapat-pendapat bahwa keberadaaan ICC akan bertentangan atau mengganggu prinsip-prinsip kedaulatan yang sangat dihormati dalam hukum internasional.

Dengan kedudukan sebagai institusi komplementer atau sekunder sebagaimana ditetapkan di atas, jurisdiksi utama adalah tetap di tangan institusi nasional. Hukum nasional didahulukan untuk diterapkan terhadap kejahatan-kejahatan internasional yang terjadi di wilayah negara yang bersangkutan. ICC hanya dapat mengadili suatu praktik kejahatan kemanusiaan, kejahatan perang, kejahatan agresi dan genocide sepanjang pengadilan domestik tidak mau atau tidak mampu melaksanakan fungsinya. Pasal 17 tentang issues of admissibility menyatakan bahwa suatu kasus tidak dapat diterima (inadmissible) oleh ICC bilamana:

a. kasus tersebut sedang diinvestigasi atau dituntut (prosecuted) oleh negara yang mempunyai yurisdiksi atas itu, kecuali jika negara tidak mau atau tidak mampu melaksanakan investigasi atau penuntutan

b. kasus sudah diinvestigasi oleh negara yang memiliki yurisdiksi atas itu dan negara sudah menetapkan untuk tidak melanjutkan penuntutan pada orang yang bersangkutan, kecuali jika keputusan tersebut dihasilkan dari ketidakmauan atau ketidakmapuan negara melakukan penuntutan

c. kasus tidak cukup kuat untuk aksi selanjutnya oleh ICC

Dalam upaya menetapkan adanya unwillingness suatu negara, ICC harus memperhatikan prinsip due process yang diakui oleh Hukum Internasional sebagai berikut:

a. proses pengadilan diambil atau putusan dibuat dengan maksud untuk melindungi orang yang seharusnya bertanggung jawab terhadap kejahatan-kejahatan yang menjadi yurisdiksi ICC

b. ada penundaan yang tidak dibenarkan dalam proses peradilan, yang tidak konsisten dengan tujuan untuk memberi keadilan pada tertuduh

c. proses peradilan tidak dilaksanakan dengan bebas atau memihak. dan dilaksanakan dengan cara dan dalam situasi tertentu, yang tidak sesuai dengan tujuan untuk membawa orang yang dituduh pada keadilan

Untuk menetapkan ketidakmampuan (inability) negara, ICC harus mempertimbangkan apakah ada kegagalan keseluruhan atau pada substansi-subastansi tertentu ataukah tidak tersedianya sistem peradilan nasional, negara

${ }^{24}$ Pasal 1 Statuta menyatakan bahwa an ICC is hereby established it shall be a permanent institusion and shall have the power to exercise its jurisdiction over persons for the........ and shall be complementary to national criminal jurisdiction....... 
tidak dapat menangkap tertuduh, tidak dapat memperoleh bukti-bukti dan kesaksian penting, atau ketidakmampuan yang lain untuk melaksanakan sendiri proses peradilan ${ }^{25}$

Dengan kedudukannya yang hanya sebagai institusi pelengkap pengadilan domestik dapat diduga negara yang mengalami kasus seperti Indonesia misalnya tentu akan berjuang semaksimal mungkin untuk mengadili sendiri warga negaranya yang dituduh melakukan kejahatan-kejahatan yang menjadi yurisdiksi ICC. Kasus Kamboja dimana Pol Pot, dituduh melakukan pembantaian terhadap sekitar dua juta rakyat kamboja adalah contoh yang dapat dikemukakan. Meskipun banyak pihak menginginkan digelarnya pengadilan internasional bagi Pol Pot namun saat ini hal tersebut belum dapat terwujud karena pemerintah Kamboja berkehendak mengadili sendiri yang bersangkutan. Pengadilan internasional dipandang merendahkan kedaulatan Kamboja.. Kasus lain adalah perlindungan yang diberikan pemerintah Chili terhadap Augusto Pinochet yang dituduh melakukan penghilangan dan pembunuhan lawan-lawan politik selama masa pemerintahannya antara 1973-1983. ${ }^{26}$

Hal ketiga yang juga diprediksikan dapat menjadi hambatan bagi ICC adalah tidak adanya ketentuan yang memberikan otoritas pada ICC khususnya bagi penuntut umum untuk memaksa suatu negara menyerahkan bukti-bukti, tertuduh, maupun saksi-saksi yang diperlukan untuk kepentingan investigasi dan proses peradilan. Dengan demikian, semuanya tergantung pada iktikad baik negara-negara peserta dalam bekerjasama dengan ICC. Masalah kerjasama memang diatur dalam bab tersendiri, yakni bab- 9 tentang kerjasama internasional dan bantuan judisial, namun ketentuan di sana hanya menetapkan kewajiban bagi negara peserta untuk bekerjasama sepenuhnya dengan ICC ${ }^{27}$ . Selanjutnya dinyatakan pula oleh Pasal 87 (1) Statuta bahwa ICC memiliki otoritas untuk meminta negara peserta bekerjasama . Namun demikian tidak ada ketentuan yang mengatur bagaimana bila negara peserta ternyata tidak mau atau tidak bisa diajak kerjasama untuk kepentingan investigasi dan proses peradilan. Pada akhirnya dapat disimpulkan bahwa penegakkan hukum oleh ICC akan sangat tergantung pada kerjasama masyarakat internasional, dari negara asal para tertuduh, negara di mana tertuduh berada, juga masyarakat internasional secara keseluruhan untuk memaksa negara yang tidak mau bekerjasama dengan ICC agar melaksanakan kewajibannya.

\section{Pengadilan Internasional dan Kasus Timor Timur}

Kesimpulan dari Komisi Penyelidik Pelanggaran (KPP) HAM Timor Timur

\section{${ }^{25}$ Pasal 17 (3) Statuta Roma 1998}

${ }^{26}$ Kompas 16 September 2000

${ }^{27}$ Pasal 86 Statuta menetapkan bahwa States parties shall, in accordance with the provisions of this statute, cooperate fully with the Court in its investigationand prosecution of crimes within the jurisdiction of the Court 
menunjukan bahwa telah terjadi pelanggaran HAM berat di daerah tersebut pasca jajak pendapat 30 Agustus 1999. Pelanggaran dilakukan secara terencana, sistematis, dalam skala besar dan luas berupa pembunuhan massal. Pembunuhan masal yang menimbulkan banyak korban penduduk sipil dilakukan dnegan sistematik dan kejam yang terjadi di berbagai tempat. Pembunuhan masal tersebut umumnya terjadi di tempattempat perlindungan umum seperti gereja, kantor polisi dan markas militer. Senjata yang digunakan kelompok milisi bersama atau dengan dukungan aparat militer atau dibiarkan terjadinya oleh aparat militer dan kepolisian adalah senata tajam dan senjata api. ${ }^{28}$

Bentuk pelanggaran lainnya adalah penyiksaan dan penganiayaan. Penyiksaan dan penganiayaan tersebut dilakukan dalam skala besar, luas dan sistematik terhadap penduduk sipil pro kemerdekaan. Penyiksaan dan penganiayaan terjadi dalam berbagai kesempatan yaitu sebelum pembunuhan dilakukan dan setelah penangkapan sewenangwenang untuk tujuan-tujuan memeras informasi dari si korban. ${ }^{29}$

Pelanggaran HAM lainnya adalah penghilangan paksa yang dilakukan dengan pola sebagai berikut: ${ }^{30}$

a. dalam rangka rekruitmen anggota milisi. Hilangnya sejumlah warga sipil merupakan akibat penolakan mereka untuk dijadikan anggota milisi

b. penghilangan paksa juga terjadi sebagai usaha penundukan terhadap warga pendukung kemerdekaan, dan

c. penghilangan paksa terhadap sejumlah korban dari kalangan mahasiswa dan warga pendukung kemerdekaan juga dilaporkan sebagai kelanjutan dari aktivitas milisi di tempat-tempat pengungsian

Di samping itu, pelanggaran berat lainnya adah perbudakan seksual dan perkosaan (kekerasan terhadap perempuan) yang terjadi di rumah, markas militer dan tempat-tempat pengungsian baik sebelum dan sesudah jajak pendapat, pembumihangusan, pemindahan dan pengungsian paksa, perusakkan serta penghilangan barang bukti. ${ }^{31}$

Berkaitan dengan pelanggaran $\mathrm{HAM}$ berat yang terjadi di Timor-Timur khususnya juga dalam kasus-kasus lain seperti Semanggi I dan II, Tanjung Priok dan lain-lain adalah adanya anggapan banyak bahwa apabila Indonesia tidak menggelar peradilan bagi pelanggaran di Timor-Timur, maka akan di ambil alih oleh ICC. Berdasarkan paparan di atas sangat kecil kemungkinan, bahkan mustahil ditinjau dari ketentuan hukum yang berlaku hal itu terjadi. Statuta Roma sampai saat ini belum berlaku, sehingga otomatis ICC belum dapat melaksanakan fungsi-fungsinya. Kalaupun

${ }^{28}$ Pernyataan Komisi Nasional Hak Asasi Manusia (Komnas HAM) tentang Kondisi HAM di Timor Timur Pasca Jajag pendapat, sebagaimana dikutip oleh Salman Luthan dalam "Relevansi Pengadilan Pidana Internasional Bagi Perlindungan Hak Asasi Manusia." Jurnal Hukum No.15 Vol 7 Desember 2000. HIm. 86.

${ }^{29} \mathrm{lbid}$.

${ }^{30} /$ bid.

${ }^{31} /$ bid. 
statuta sudah berlaku, Indonesia belum menjadi negara peserta yang berarti tidak terkena yurisdiksi ICC. Seandainya dalam waktu dekat statuta berlaku dan Indonesia menjadi negara peserta, kasus Timor Timur apalagi kasus Semanggi I dan II, Kasus Tanjung Priok ${ }^{32}$ dan lain-lain juga tetap tidak dapat diadili oleh ICC sebab ICC hanya mempunyai yurisdiksi terhadap kasus-kasus yang terjadi setelah Indonesia menjadi peserta statuta. ${ }^{33}$ Kesalahpahaman yang selama ini terjadi di berbagai mass media kasus-kasus tersebut dapat diajukan ke ICC.

Meskipun sangat kecil atau tidak mungkin kasus Timor Timur diadili oleh ICC tidak berarti Indonesia bisa melaksanakan proses peradilan kasus Timor Timur dengan seenaknya Peradilan internasional tetap mungkin digelar seandainya Indonesia tidak sungguh-sungguh melaksanakan proses peradilan nasional, hanya saja tidak melalui ICC. Pengadilan internasional yang mungkin dibentuk adalah pengadilan internasional $\mathrm{Ad}$ Hoc sebagaimana yang dibentuk untuk kasus Yugoslavia dan Rwanda.

\section{Simpulan}

Dibentuknya pengadilan-pengadilan ad hoc serta didirikannya ICC untuk mengadili para pelaku kejahatan terhadap kemanusiaan, kejahatan perang, genocide; dan kejahatan agresi merupakan keinginan masyarakat internasional untuk melaksanakn penegakkan hukum atas kejahatan-kejahatan yang dipandang merupakan pelanggaran yang sangat serius terhadap kehidupan manusia. Baik pengadilan-pengadilan ad hoc maupun ICC efektifitasnya sangat tergantung pada dukungan dan kerja sama masyarakat internasional secara keseluruhan. Pembatasanpembatasan yurisdiksi serta serta kelemahankelemahan lain yang ada dalam statuta dapat menimbulkan skeptis dan keraguan terhadap efektifitas ICC sebagai institusi permenen yang diharapkan dapat menegakan pelanggaranpelanggaran HAM berat. ᄀ

\section{Daftar Pustaka}

Boer Mauna. 2000. Hukum Internasional Pengertian, Peranan dan Fungsi dalam Era Dinamika Global. Bandung: Alumni.

Michael Akehurst. 1983. A Modern Introduction to International Law. Olndon: George Allan \& Unwin (Publishers) Ltd.

Sumaryo Suryokusumo. 1997. Studi Kasus Organisasi Internasional. Edisi II. Bandung: Alumni.

${ }^{32}$ Kasus Semanggi I dan II adalah kasus tewasnya beberapa mahasiswa yang berdemonstrasi meminta lengsernya Soeharto dari kursi kepresidenan pada Mei 1998. Hasil penyelidikan menunjukkan digunakannya peluru tajam oleh aparat keamanan dalam menghadapi para demonstran tersebut. Kasus Tanjung Priuk adalah kasus yang berkaitan dengan tragedi Malari, Malapetaka 15 Januari, tewasnya warga serta demonstran yang menentang kebijakan pemerintah akibat kekerasan yang dilakukan aparat keamanan.

${ }^{33}$ Pasal 11 ayat 1 Statuta Roma menegaskan bahwa "The Court has jurisdiction only with respect to crimes committed after the entry into force of this Statute" 
Salman Luthan dalam "Relevansi Pengadilan Pidana Internasional Bagi Perlindungan Hak Asasi Manusia." Jurnal Hukum No. 15 Vol 7 Desember 2000.

Romli Atmasasmita. 1995. Pengantar Hukum Pidana Internasional. Bandung: Eresco.

Roberge, Maria Claudia. "Jurisdiction of ad hoc Tribunal for The Former Yugoslavia \& Rwanda over Crimes Against Humanity and Genocide." Dalam International Review of Red Cross. No.322. NopemberDesember 1997.

Ronny Rahman Nitibaskara. "Pengadilan HAM dan Masyarakat Internasional." Dalam harian Kompas. Tanggal 20 Pebruari 2002.

Thomas M. Franck. 1999. Fairness in International Law and Institution. Oxford: Clarendon Press

Harian Kompas 16 September 2000.

Harian Kompas. Tanggal 19 Februari 2000

Harian Kompas. Tanggal 2 Juli 2001.

Harian Kompas. Tanggal 9 Agustus 2000.

A Global Agenda, Issues before the $54^{\text {th }}$ General Assembly of The U.N. 19992000 Edition.

International Herald Tribune. March 4-5. 2000. 